\title{
Java and Outer Island: Economic Inequality and Inter-Island Shipping Policy in Indonesia Until the 1960s
}

\author{
Haryono Rinardi* \\ Department of History ;Faculty of Humanity; Diponegoro University
}

\begin{abstract}
This article tries to explain the relationship between economic inequality in Java and outer Java, also the inter-island shipping policy in Indonesia until the 1960s by using the historical methods. This study proves that the inequality had occurred since the colonial era when the Dutch colonial government focused on developing infrastructure on Java as the center of its government. When withdrawn again, inequality has occurred since pre-colonial times. The inter-island shipping policy that places Java as the center of shipping has increasingly encouraged economic inequality.
\end{abstract}

Keywords: Economic Inequality; Inter-island Shipping; Historical Methods; Java and Outer Java; Colonial Era

\section{Introduction}

Inequality and dichotomy between Java Island and other regions in Indonesia are not only real but visible in terminology. The Colonial Government referred to areas outer Java as Buitenbezittingen and then buitengewesten. [1] Therefore it is not surprising that Clifford Geertz, an anthropologist, distinguishes the interior regions of Central Java and East Java and as Indonesia within. Other areas have referred to as outer Indonesia [2]. Obviously, the two regions have different types. The Indonesian region has culturally influenced by HinduBuddhist culture. It can seen from the existence of various temples in the P. Java region. Another influence is the persistence of the presence of cultural arts, which is a relic of HinduBuddhist culture in Indonesia, such as the Ramayana and Mahabarata epics. All of these will not found in the area which Geertz later called Indonesia outer.

In the economic field, there are very striking differences between the two regions. An exciting condition then occurred, namely a symbiotic relationship between Java and outer Java. The island of Java is ecologically a rice field area. Areas outer Java are cultivated areas. Java Island is a food crop-producing area, i.e., rice, which has exported to agricultural land.

On the other hand, farming areas produce trade crops that sell well in international markets such as; nutmeg, cloves, pepper, forest, and mining products [3]. But on the other hand, regions in outer Java do not produce food crops. They need food supplies from other

Corresponding author : haryonorinardi@yahoo.com 
areas. With this condition, there is a symbiotic relationship through a mutually beneficial trade relationship between the two regions, with Java Island being a kind of center. In contrast, the outer areas of Java act as a kind of peripheral.

Trading ports along the north coast of Java Island played an important role in shipping and trading activities at that time. Therefore, Java Island acted as a hub of trade and shipping during the pre-colonial period. Thus, it is reasonable that Javanese traders played an important role in shipping and trade activities during the pre-colonial period [4]. Javanese traders were the link in shipping and trade activities between Maluku and Malacca. The role of Javanese traders was to send the spices from Maluku to the Port of Malacca export. Previously they brought rice to be exchanged with spices in Maluku. From Malacca, Javanese traders brought luxury goods, which were exchanged for rice on the north coast of Java Island. The rice is then delivered to Maluku. And so on, the role of Javanese traders in the shipping and trading activities of Maluku-Malacca during the pre-colonial period [5].

By this condition, it was evident that Java island plays a more critical role in shipping and trade activities in the archipelago, which later became known as Indonesia. Therefore, throughout the pre-colonial period, the trading ports that existed along the northern coast of Java Island enjoyed prosperity from shipping and trading activities. Trading merchants such as Jepara, Gresik, Tuban, Sunda Kelapa, and Banten were "metropolitan" cities at the time. They got great advantages from shipping and trade activities. This condition is different from some regions in outer Java, although the region was the main commodity producer of international trade at that time. Maluku regions, which are producers of cloves and nutmeg, are still inferior to Banten and Jepara. The same thing also happened with Banjar, which is the producer of Pepper, clearly not a comparison with Sunda Kelapa or Tuban. It shows that Java island "takes" advantage of economic activities that took place in the archipelago, which became known as Indonesia. The situation indicates that the exploitation of Java against the outer of Java did not only take place during the independence period, but it had been running before independence, even before the arrival of the Western Nations. With that background, this article tries to reveal how the economic relations and shipping of Java and outer Java during the colonial period and the beginning of independence, especially before the New Order.

\section{Methods}

This article uses a historical method that runs in four stages, namely, the first step of heuristic is the process of finding and gathering sources, both primary and secondary data used in the research and preparation of this paper [6]. The primary sources are obtained from the studies in various libraries and institutions which store the documents or sources needed for this paper. The National Library of the Republic of Indonesia is an institution that keeps many primary sources that are useful for writing this article. One of them is "Suluh Nautika, Magazine of the Ministry of Learning." Suluh Nautika is the official magazine of the Ministry of Shipping. A variety of important information is contained in the magazine, ranging from coastal shipping regulations to people's shipping activities.

Another primary source is the Decree of the Minister of Sea Transportation No. DRP 3/6/2 March 25, 1966, Pelajaran Djaring2 Pelajaran Nusantara. We can find out the official shipping routes permitted by the government in the pre-New Order era by using this primary source. Other sources used in writing this article are gender sources, i.e., sources that have been processed or used to write books or articles, such as Clemens, A.H.P., et al., Regional Patterns in Foreign Trade 1911-1940 which was published by The Royal Tropical Institute, Amsterdam. The book gives a lot of information about shipping and trading activities in various ports of Java and Java outer the period of the late nineteenth and early twentieth 
centuries. Thus, the information contained in the book can be a guide that gives an overview of the shipping and trading activities of Java and outer Java.

The second stage in the historical method is a criticism which is carried out by paying attention to the statements that are in a historical source. After doing heuristics and criticism, an understanding of historical facts will be obtained. The crucial facts that emerged in the writing of this article are the first until the colonial period of Java Island is still an exporter of food for regions in outer Java. Secondly, P. Java is also a textile exporter for regions in outer Java. Third, the regions in outer Java are exports of agricultural products in the fields, namely copra to Java. The four Javanese islands were still the center of economic development in Indonesia during the colonial period.

After criticism, the next stage is the interpretation of the facts Interpretations are made of historical facts, for example, based on the facts that can be said that the exploitation of Java against outer Java, especially in the field of shipping and trade had taken place during the colonial period. The last stage, namely historiography or the process of compiling data into systematic writing so that it can be understood as a scientific paper.

\section{Result and Discussion}

\subsection{Shipping and Trading in Java and Outer Islands in Colonial Periods}

The arrival of the West Nation emphasized the position of Java towards outer Java. The relocation of the VOC headquarters from Ambon to Batavia could be said to be an embryo of Javanese dominance over the outer Java during the colonial period. The implementation of the Cultivation System is the next step towards the dominance of the Javanese position. The Dutch colonial government focused on the establishment of the infrastructure in Java, building such things as roads, railways, telegraphs, bridges, irrigation systems, etc. to encourage Java to produce more profitable commodities for the European market. The implication of this policy was the Outer Islands were ignored, while Java was increasingly developed as the favorite. Batavia was projected to become the center of shipping and trade in Southeast Asia, first competing with and then replacing the role of Malacca [7].

The rapid development plantations and their impact increasingly put Java as the core area of Indonesia. The development of the railroad network from the ports of Jakarta, Semarang, and Surabaya hinterland places Java as an area with an extensive rail network that exceeds other places in Southeast Asia. The development of transportation and communication facilities in Java continued to develop during the XIX century. The first telegraph line was designed 1856 from Jakarta to the Governor General's Palace in Bogor. Then, Java island combined with international networks via Singapore. Gradually important cities in Java received telegraph connections. Subsequently, telephone systems began to be built in Jakarta, Semarang, and Surabaya in the 1880s. Jakarta has even become one of the first cities in the world to use new electric tram technology [8]. Therefore, the island of Java in the early twentieth century was the most integrated and modern economic unit between Bengal and Japan. Technology has been applied to communication and transportation networks in the export-oriented sugar industry, irrigation networks, metal processing, etc [9].

This situation is very contrast to be compared to any region outer Java, even other Southeast Asian regions, except for Penang and Singapore. The only modern enclave outer Java at that time was a rapidly growing plantation district around Medan. With a slight exclusion of several small ports, the rest of the Indonesian Archipelago is not yet part of the modern world. At the end of the nineteenth century, the Malay Peninsula was still a series of rough tin mining cities with the only good transportation network being the steamboat. The city of Manila, which later became the capital of the Philippines, was almost still primitive 
by Javanese standards [10]. Therefore, Java Island in the early XX century was an area with advanced technology and infrastructure compared to other regions.

The privilege of Java Island compared to other regions in Indonesia can be known from the infrastructure, including ports. During the early twentieth century, Java Island, which was less than $10 \%$ of Indonesia's territory, was served by more ports than any other island in Indonesia. Six ports in Java Island serve shipping and international trade activities. The six ports are; Batavia, Cirebon, Semarang, Surabaya, Panarukan, and Banyuwangi. That number is a little almost the same as the number of ports serving other regions in Indonesia [11]. Based on the record, it can be seen that ports on Java Island were still the main destination for ships from abroad on their voyages to Indonesia during the early twentieth century. More clearly about the development of ports in Java involved in shipping and international trade activities can be seen in the table below.

Table 1 Development of International Ship Visits at the Main Ports of Java Island 1900-1920.

\begin{tabular}{|c|c|c|c|c|c|c|c|}
\hline Year & Batavia & Cirebon & Semarang & Surabaya & Panarukan & Banyuwangi & Total \\
\hline 1900 & 233 & 36 & 60 & 208 & 0 & 2 & 539 \\
\hline 1901 & 250 & 33 & 112 & 171 & 4 & 0 & 570 \\
\hline 1902 & 278 & 14 & 90 & 174 & 6 & 0 & 557 \\
\hline 1903 & 278 & 10 & 75 & 174 & 0 & 5 & 542 \\
\hline 1904 & 272 & 12 & 49 & 152 & 0 & 5 & 490 \\
\hline 1905 & 307 & 22 & 43 & 186 & 0 & 0 & 558 \\
\hline 1906 & 270 & 13 & 52 & 191 & 2 & 3 & 531 \\
\hline 1907 & 263 & 13 & 48 & 164 & 0 & 5 & 493 \\
\hline 1908 & 280 & 6 & 44 & 195 & 0 & 3 & 528 \\
\hline 1909 & 271 & 12 & 32 & 198 & 0 & 5 & 518 \\
\hline 1910 & 278 & 10 & 57 & 221 & 0 & 5 & 571 \\
\hline 1911 & 391 & 17 & 50 & 118 & 3 & 8 & 587 \\
\hline 1912 & 395 & 20 & 49 & 174 & 5 & 16 & 659 \\
\hline 1913 & 445 & 24 & 48 & 180 & 10 & 28 & 738 \\
\hline 1914 & 435 & 15 & 40 & 137 & 5 & 34 & 666 \\
\hline 1915 & 423 & 8 & 41 & 137 & 5 & 21 & 648 \\
\hline 1916 & 467 & 12 & 22 & 129 & 4 & 17 & 651 \\
\hline 1917 & 343 & 21 & 35 & 166 & 3 & 11 & 579 \\
\hline 1918 & 313 & 27 & 51 & 189 & 3 & 10 & 593 \\
\hline 1919 & 419 & 16 & 64 & 223 & 11 & 15 & 748 \\
\hline 1920 & 478 & 19 & 39 & 189 & 2 & 14 & 741 \\
\hline
\end{tabular}

Source: L.J. Touwen, Shipping And Trade In The Java Sea Region (Semarang:Universitas Diponegoro Press, 2000), p. 25.

Based on the data in the table above, it is known that Batavia was the main Port on Java during the early XX century. There are two exciting things about the Port of Batavia. First, the number of ship visits from abroad increased during the period 1900-1920. Batavia was recorded to have received foreign ship visits above 300 times since the period of 1911 . Secondly, since 1902 based on its percentage Batavia received more than 50\% of the total number of international ships visiting all significant ports of Java. The table above also shows Surabaya to be the second busiest Port on the island of Java in matters of international ship visits. That is reasonable because Surabaya in the early XX century had a developed industry compared to other places throughout Indonesia. In the early twentieth century, Surabaya was 
ranked equal to Calcutta, Bombay, and Osaka among the leading industrial centres in Asia [12].

The table above illustrates that the Port of Batavia is the most important Port on Java Island. The high visit of foreign ships to the ports in Java can be seen, more due to the large number of foreign ships that dock in Batavia. In other words, there is a massive imbalance in terms of shipping and trade dynamics in Java. The visit of foreign ships throughout the ports of Java Island was concentrated only on the Port of Batavia. Other ports, although they still receive ships from abroad, are far outnumbered by Batavia.

By putting aside Belawan, Padang, and Ambon a little, ports on the outer Java also receive a lot of ship visits from abroad. The table below will show the development of foreign ships arriving at six major ports in outer Java. 
Table 2 Development of International Ship Visits at Main Ports outer Java 1900-1920.

\begin{tabular}{|c|c|c|c|c|c|c|c}
\hline Year & Palembang & Mentok & Pontianak & Banjarmasin & Makassar & Singaraja & Total \\
\hline 1900 & 76 & 109 & 140 & 37 & 55 & 17 & 434 \\
\hline 1901 & 58 & 104 & 145 & 47 & 52 & 27 & 433 \\
\hline 1902 & 49 & 87 & 142 & 44 & 80 & 26 & 428 \\
\hline 1903 & 54 & 117 & 107 & 58 & 57 & 20 & 413 \\
\hline 1904 & 124 & 84 & 110 & 69 & 40 & 31 & 458 \\
\hline 1905 & 105 & 67 & 120 & 0 & 34 & 44 & 370 \\
\hline 1906 & 95 & 66 & 106 & 39 & 40 & 39 & 385 \\
\hline 1907 & 87 & 87 & 151 & 46 & 27 & 40 & 438 \\
\hline 1908 & 84 & 112 & 186 & 89 & 34 & 25 & 531 \\
\hline 1909 & 51 & 123 & 171 & 89 & 21 & 22 & 477 \\
\hline 1910 & 19 & 135 & 160 & 48 & 23 & 22 & 407 \\
\hline 1911 & 23 & 119 & 100 & 63 & 26 & 17 & 348 \\
\hline 1912 & 63 & 131 & 82 & 36 & 27 & 15 & 354 \\
\hline
\end{tabular}




\begin{tabular}{|c|c|c|c|c|c|c|c}
\hline 1913 & 84 & 133 & 116 & 35 & 34 & 20 & 424 \\
\hline 1914 & 96 & 138 & 143 & 24 & 34 & 9 & 444 \\
\hline 1915 & 90 & 112 & 102 & 20 & 23 & 6 & 353 \\
\hline 1916 & 27 & 78 & 95 & 7 & 19 & 2 & 228 \\
\hline 1917 & 15 & 40 & 61 & 3 & 17 & 5 & 141 \\
\hline 1918 & 47 & 36 & 65 & 5 & 27 & 5 & 182 \\
\hline 1919 & 74 & 43 & 115 & 8 & 62 & 5 & 307 \\
\hline 1920 & 15 & 24 & 100 & 9 & 23 & 0 & 171 \\
\hline
\end{tabular}

Source: L.J. Touwen, Shipping And Trade, 2000, p. 26-27.

With the data above, it is clear that Indonesia's economic development since the colonial period has begun to be biased. Java island is the central destination for economic activity in Indonesia. By the increasing number of foreign ships visiting ports in Java, it can be indicating. This was reinforced by the large number of finished products imported into Java Island during the early XX century period. The table below will overview the percentage of imports of the main ports in Java to the total imports of all ports in Indonesia in the early twentieth century.

Table 3. Percentage of Imports of Main Commodities from Three Major Ports in Java Against the Total Imports of Indonesia in the 1915-1925 Period.

\begin{tabular}{|l|l|l|l|l|l|l|l|l|l|l|l|l|}
\hline \multicolumn{3}{|c|}{ Batavia } & \multicolumn{3}{c|}{ Semarang } & \multicolumn{3}{c|}{ Surabaya } & \multicolumn{3}{c|}{ Total } \\
\hline Machine & Textile & Rice & Machine & Textile & Rice & Machine & Textile & Rice & Machine & Textile & Rice \\
\hline 15 & 20 & 9 & 12 & 20 & 10 & 32 & 22 & 27 & 59 & 62 & 46 \\
\hline 16 & 23 & 7 & 17 & 18 & 10 & 33 & 34 & 31 & 66 & 75 & 48 \\
\hline 19 & 23 & 6 & 14 & 16 & 11 & 31 & 34 & 31 & 64 & 73 & 48 \\
\hline 25 & 25 & 7 & 8 & 15 & 8 & 37 & 34 & 33 & 70 & 74 & 49 \\
\hline 22 & 23 & 3 & 10 & 19 & 4 & 36 & 29 & 2 & 61 & 71 & 9 \\
\hline 26 & 17 & 0 & 10 & 21 & 0 & 31 & 31 & 0 & 68 & 69 & 0 \\
\hline 15 & 21 & 10 & 11 & 20 & 18 & 35 & 32 & 38 & 61 & 76 & 66 \\
\hline 15 & 19 & 8 & 19 & 22 & 13 & 29 & 34 & 33 & 63 & 75 & 54 \\
\hline 18 & 21 & 10 & 17 & 21 & 5 & 26 & 31 & 24 & 61 & 73 & 39 \\
\hline 13 & 19 & 13 & 10 & 21 & 6 & 28 & 35 & 23 & 51 & 75 & 42 \\
\hline 12 & 21 & 6 & 10 & 18 & 6 & 28 & 31 & 32 & 50 & 70 & 44 \\
\hline
\end{tabular}

Source: L.J. Touwen, Shipping And Trade, 2000, p. 123-125.

Based on the data above, it can be seen that the import of machines to Java accounts for more than $50 \%$ of the total imports of Indonesian machinery during the period 1915-1925. It shows that P. Java has been the center of the Indonesian industry during the early XX century. Other commodities used as indicators are textiles, which is one of the products with consumptive properties. The percentage of Batavia, Semarang, and Surabaya port imports is even above $60 \%$ compared to the total Indonesian textile imports. This shows that the 
population level of the Java population is much higher than other islands in Indonesia in the same period. The percentage of rice indicates slightly different conditions. During the period 1915-1925, the figure was around 40\%, in 1919 even only $9 \%$, a year later even the figure was $0 \%$. This is probably related to the policies adopted by some countries in Asia who choose not to export rice in specific periods. The figures in the table above also indicate that Java island is the center of manufacturing, as well as consumer activity in Indonesia. This condition can cause Java Island to take more foreign exchange compared to other islands in Indonesia.

The amount of the economy on the island of Java in the early twentieth century resulted in an imbalance of trade relations between Java and outer Java. In the commodity trade relationship between Java and outer Java, Java Island enjoys a greater trade surplus. In the end, Java will always enjoy the benefits of its relations with outer Java. In rather harsh words, some advantages flow to Java from outer Java. The table below can provide an overview of trade development and comparison between Java and outer Java.

Table 4 Outer Java and Java Trads for Some Main Commodities in the Period of 1917-1928 (f.1000)

\begin{tabular}{l|l|l|l|l|l|l|l|l|l|}
\hline \multicolumn{2}{c|}{ Copra } & \multicolumn{2}{c|}{ Crude Oil } & \multicolumn{2}{c|}{ Rice } & \multicolumn{2}{c|}{ Machine } & \multicolumn{2}{c|}{ Textile } \\
\hline Import & Export & Import & Export & Import & Export & Import & Export & Import & Export \\
\hline 0 & 7.650 & 1.470 & 7.647 & 3.782 & 2.571 & 5.002 & 728 & 16.961 & 1.436 \\
\hline 0 & 7.581 & 1.193 & 4.244 & 1.796 & 1.759 & 9.667 & 1.236 & 12.650 & 870 \\
\hline 0 & 18.568 & 1.671 & 6.909 & 3.628 & 1.689 & 8.201 & 1.518 & 15.185 & 2.886 \\
\hline 1.291 & 12.369 & 2 & 14 & 11.512 & 4.169 & 19.336 & 70 & 20.131 & 1.331 \\
\hline 6 & 1.855 & 0 & 0 & 2.796 & 1.420 & 5.856 & 2.044 & 16.350 & 3.073 \\
\hline 5 & 1.276 & 1.644 & 21.485 & 2.798 & 2.289 & 5.766 & 1.340 & 20.727 & 1.106 \\
\hline 6 & 1.258 & 3.168 & 11.055 & 2.563 & 2.233 & 5.537 & 982 & 21.815 & 930 \\
\hline 7 & 2.122 & 1.753 & 15.896 & 5.939 & 866 & 6.606 & 1.034 & 26.377 & 1.012 \\
\hline 1 & 3.066 & 4.910 & 16.573 & 5.344 & 813 & 7.149 & 1.389 & 25.390 & 1.353 \\
\hline 18 & 8.991 & 5.875 & 16.818 & 6.233 & 1.608 & 8.961 & 2.280 & 25.670 & 1.165 \\
\hline 2 & 6.129 & 3.740 & 12.695 & 5.025 & 2.001 & 8.881 & 1.975 & 25.108 & 1.510 \\
\hline
\end{tabular}

Source: L.J. Touwen, Shipping And Trade, 2000, p. 128.

Based on the data above, it can be seen that the trading relations on Java and outer Java for several commodities gave Java a surplus, except for copra and the copra petroleum. The exports outer of Java to Java are dominating the copra trade on the outer Java and Java. During the period 1917-1928, the highest import value outer Java for the copra trade with Java recorded in 1920. At that time, the figure was f.1.29 million. After that, the number of copra imports from Java fell back to the range of thousands of guilders. However, one thing that must be noted is the possibility of copra exports to Java in the context of re-export abroad. In other words, the position of Java in the copra trade outer Java is as a transit port to send the copra-copra abroad. Thus, Java again benefited from sending copra-copra from outer Java abroad. The same thing might also be exact in the Java and Outer Java trade in petroleum. 
Java is likely to act as an intermediary or transit port outer Java. That causes Java to always benefit from exporters from outer Java. This condition has caused the emergence of Java and outer Java. Three other commodities, in the Java trade and outer Java, clearly benefit Java. In this case, Java is enjoying its business in outer Java.

\subsection{Shipping During Independence}

In the category of coastal shipping or inter-insular shipping and ocean shipping are including Large commercial vessel shipping. Ships that serving this type of cruise are ships that are weighing above 100 BRT. Regarding licensing issues, different institutions permit both types of shipping. On coastal shipping permits, it has been regulated in Government Regulation No. 47 of 1957. Its Implementing Regulations then strengthened the regulation. The registration of the shipping permit is carried out by the Maritime Transportation Licensing Committee, the Ministry of Shipping. On Ocean Shipping, which has the authority to transport export-import goods. Registration is made to the Department of Economic Studies, Ministry of Education.

The government by permitting sea transportation companies to regulate sea transportation and trade in Indonesia after the eviction of KPM. Through Minister of Sea Transportation Decree No. DRP. 3/6/2 March 25, 1966, About the Djaring Lessons 2 The Indonesian Archipelago Lessons set various official shipping routes in Indonesian waters. With this regulation, the government established Jakarta's Tanjung Priok Port, Surabaya Port, Belawan Port, and Makassar Port as the fulcrum of various shipping routes in Indonesia. Jakarta and Surabaya Tanjung Priok Ports are the fulcra of shipping routes to different Indonesian ports both in the western and eastern regions. The Port of Belawan is the basis for shipping and sea transportation serving routes from Sumatra to several ports on the island of Java. Makassar port is the basis for shipping and sea transportation by traveling from Sulawesi Island to several ports in eastern Indonesia and Java. Through this regulation, the government then established several shipping companies with their ships to fill several shipping routes/routes in Indonesia.

By the validation of this regulation, the government has established several major ports in Indonesia as a platform for inter-island shipping activities. Some of the ports are Surabaya's Tanjung Perak, Jakarta's Tanjung Priok, Medan's Belawan, and Makassar. By looking at the determination of the Port, which becomes the axis for inter-island shipping activities, it can be seen the dominance of Java over outer Java, because most of the interisland shipping routes use the Ports in Java as the axis. Unequal conditions will be increasingly apparent if you pay attention to the number of shipping routes or routes available at each Port. Surabaya's Tanjung Perak Harbor has ten shipping routes and routes going back and forth to Surabaya.

Something similar also exists at Tanjung Priok Port, which has twelve shipping routes going and going back to Jakarta. The exciting thing is that some of the routes are shipping routes to eastern Indonesia. In this case, four shipping routes to eastern Indonesia depart and return to Tanjung Priok, Jakarta. This cruise route visits several ports in East Java, Bali, or Nusa Tenggara before heading to Sulawesi. Four shipping routes serve this route.

Governments in regions outer Java have designated two ports as the axis, namely Belawan Port in North Sumatra, as a base to serve routes from Sumatra to several parts of Indonesia. In this case, two shipping routes are originating from the Port of Belawan. The first route is a round trip from Belawan to Padang across the west coast of Sumatra Island. The second route is a round trip cruise route from Belawan to Jakarta, via Palembang / Jambi. In the eastern part of Indonesia, the government established the Makassar Port as the basis for serving travel routes to several ports. In this case, six shipping routes use the Makassar Port as their travel base. The first route is Makassar-Surabaya-Semarang-Tanjung Priok- 
Surabaya-Makassar. The second route is a voyage from Makassar to Banjarmasin but mainly through Pare-pare and Surabaya. The interesting thing about this shipping route is the indication of the importance of the relationship between Makassar to Surabaya to Banjarmasin, especially on Makassar to the Surabaya route. The shipping route is important because several other routes from Makassar always stop at the Surabaya port first.

The third shipping route determined by the government is the shipping route from Makassar to connect several ports on Sulawesi Island with several ports in East Kalimantan. The interesting thing about this route is that the ships have visited several ports in East Kalimantan and then returned to Makassar via Toli-toli and Donggala. After that, the ship will continue the voyage to Surabaya and continue to Tanjung Priok before returning to Makassar. Thus, this shipping route essentially connects several ports in East Kalimantan and Sulawesi with the Ports of Surabaya and Jakarta, via Makassar.

The fourth shipping route is a shipping route that connects several ports in Sulawesi, including Manado, with Tanjung Priok port. The fifth shipping route is the shipping route from Makassar to Jakarta (roundtrip) after first visiting several ports on the island of Sulawesi, especially the eastern part and the Surabaya Port. The fifth shipping route is a cruise from Makassar to several ports in the Maluku Islands (round trip). The ship then continued its journey to Surabaya via Makassar (round trip). More about this cruise route is Makassar to Bau-Bau / Banabungip to Ambon to Banda to Dobo / Tual to Ambon to Baubau to Banabungi to Makassar to Surabaya.

Based on the shipping routes above, it is clear that Java is still a pivot for shipping and trading activities in Indonesia. The condition was caused by economic growth only developed rapidly in western Indonesia, especially in Java and Bali. Historically, the economic core and modern state were formed in Java during the nineteenth century with the development of plantation economics under the Cultivation System. This condition has continued to develop since the 1970s. It is a result of the rapid industrialization of Java, supported by a large population and the existence of a much more complete development infrastructure compared to regions of outer Java. Therefore, the Javanese economy (together with Bali) reached 62\% of the total Indonesian economy in 1996. Under these conditions, the majority of the flow of goods and services enters Java and Bali, especially raw materials. Conversely, the flow of goods from Java to outer Java is in the form of manufactured goods. This condition reflects the comparative advantage pattern between Java and outer Java. With that condition, it is very reasonable if all inter-island shipping activities in Indonesia always involve ports in Java.

Related to the development of trade between Java and outer Java until the 1970s, Singgih Tri Sulistiyono, in his dissertation, emphasized that there are important things that must be considered. Firstly, Java has remained the center of interisland trade in Indonesia. Secondly, the greatest part of the inter islands trade between Java and the Outer Islands occurred between Java and the islands in western Indonesia, especially Sumatra. At the same time, $25 \%$ flowed to the eastern part of Indonesia. In the meantime, Imports of Java from the western part of Indonesia reached 66\%, while from the eastern part of Indonesia, it was only $44 \%$.

That is because, in the early 1970s, Java began to function as the distributor of imported goods and the producers and suppliers of manufactured goods (soap, batik, textiles), machines, cement, imported rice, sugar, etc. In the meantime, Java imported foodstuff; rice, maize, fish, cassava. Java also imported from the Outer Islands agricultural products; copra, rubber, coffee, wood, etc. and mining product.

By looking at inter-island shipping routes and economic development in Indonesia until the 1970s, it can be seen that Java still dominates inter-island shipping and trade. Moreover, Java enjoyed the comparative advantage of inter-island trade activities. That was due to Java importing raw materials from outer Java. On the other hand, outer Java imported 
manufactured goods from Java. Thus, outer Java will experience a deficit in trade with Java. That is because outer Java exports commodities whose value is cheaper because they are raw materials. The opposite is experienced by Java, which enjoys a comparative advantage because it imports cheaper-priced commodities but exports them at higher prices.

This condition cannot be blamed on the New Order government, because the situation had been built since pre-colonial times. Javanese traders have an important role in traditional trade in the archipelago. They are a link in the sea trade from Maluku to Malacca. It made trading ports on the north coast of Java enjoy the benefits of shipping and trading activities at that time. The situation continued when the Colonial Government came to power. The concentration of infrastructure development in Java for the benefit of the Colonial Government was one of the reasons. This condition was added by Batavia's position as the center of government, which made Java a center of colonial administration and economic activity. Another problem is the number of Javanese population, which is far more than outer Java to provide legitimacy for economic development and development in Java. On the other hand, outer Java then seemed to be ignored in development and political control in Indonesia. The Colonial Government itself only realized the importance outer Java, when a new dynamic emerged, namely the existence of James Brooke in Sarawak and the discovery of mining materials outer Java at the end of the nineteenth century. However, that puts outer Java more than 50 years behind in development compared to Java Island.

\section{Conclusion}

The inequality and dichotomy between Java and outer Java is not something simple, because it is produced by a long historical process and is not caused by a single factor. Inequality and dichotomy were born as a result of the process of shipping and sea trade in the archipelago. It was then continued by the Actions of the Colonial Government in its efforts to benefit from its colonies. The situation grew because of efforts to form a modern national state in the land of the colony, indirectly placing Java as a center while outer Java as a phery-phery. This condition continued until the independence period, which again put Java as the political and economic center in Indonesia. In inter-island trade activities, Java has a comparative advantage because it imports raw materials from outer Java while exporting manufactured materials outer Java. With these conditions, Java will continue to enjoy large profits in trade with outer Java. Java will get a surplus in inter-island trade in this situation. Thus, Java will enjoy advantages in inter-island trade relations. This is still added to the large population so that, for some people, it is natural that economic development is centered on Java.

By looking at inter-island voyages from colonial times to the end of the Old Order period, it can also be concluded that because everything is centered in Java, inter-island voyages in Indonesia are also centered in Java. Most shipping routes or routes always start or pass through ports in Java. It is because of the good flow and services during that period and also always directed to Java compared to regions outer Java. This condition is one of the reasons for the imbalance between Java and outer Java, even though Indonesia has become independent.

With that basis, it is reasonable if the Jokowi's Government plans to move the State Capital outer of Java. Perhaps that was based on the thought to eliminate or at least reduce economic inequality between Java and outer Java. At the same time, it is expected that a trickle-down effect will occur in the regions outer Java, due to massive infrastructure development. Thus, it is hoped that equality will be created in development in Indonesia. 


\section{REFERENCES}

[1] H.W. Dick, "State, nation-state and National economy", in H.W. Dick et al., The Emergence of A National Economy, An economic history of Indonesia, 1800-2000. Leiden: KITLV Press,pp. 18. (2002)

[2] See; Clifford Geertz, Involusi Pertanian. Jakarta: Bhatara Karya Aksara, (1983)

[3] In 1615 an estimated 50 junk of rice sailed from Jepara to Malacca every year. In addition, there are still junks that carry rice sailing to Banten, Johor, Patani, Jambi, Palembang. In total there are estimated to be around two hundred junks that carry rice for export to outer Java. Each junk brought one hundred tons of rice. Read more on; J.C. Van Leur, Indonesia Trade and Society. Dordrecht: Foris Publications, pp. 209. (1983)

[4] Howard Dick, "Perdagangan Antar Pulau, pengintegrasian Ekonomi dan timbulnya Suatu Perekonomian Nasional", on the Anne Booth et al. (ed), Sejarah Ekonomi Indonesia. Jakarta: LP3ES, pp. 402. (1988)

[5] About the important role of Javanese's Traders Read; Sartono Kartodirdjo dan Djoko Suryo, Sejarah Perkebunan di Indonesia, Kajian Sosial-Ekonomi (Yogyakarta: Aditya Media, 1991. p. 20-21. Read more on; M.C. Ricklefs, A History of Modern Indonesia. C 1300 to the Present. London and Basingstoke: The Mac Millan Press lts, pp. 18-19. (1981)

[6] More details about the historical methods; Check Gilbert J. Garraghan, A Giude to Historical Method. New York: Fordham University Press, 1957, pp. 33; Louis Gottschalk, Mengerti Sejarah (translated by Nugroho Notosusanto) (Jakarta: Universitas Indonesia Press, 1975, pp. 32; Nugroho Notosusanto, Masalah Penelitian Sejarah Kontemporer. Jakarta: Inti Idayu, pp.11. (1978)

[7] Singgih Tri Sulistiyono, The Java Sea Network: Patterns in the Development of Interregional shipping and Trade in The Process of National economic Integration in National, 1870s-1970s Leiden: 2003,pp. 55-56. See; H.J. Marks, The First contest for Singapore 1819-1824. The Hague: Nijhoff, pp. 252-256 (1959)

[8] H.W. Dick, State, nation-state and National economy, 2002, p. 16. See; D.G. Stibbe (eds), Encyclopaedie van Nederlandsch Indie. 's Gravenhage: Martinus Nijhoff, 1918. See; S.A. Reitsma, Korte Geschiedenis der Nederlandsch-Indische Spooren Tramwegen. Batavia: Kolff, (1928)

[9] H.W. Dick, "Nineteeth-century industrialization: A missed opportunity?" in J. Th. Lindblad, New challenges in the modern economic history of Indonesia. Leiden: Programme of Indonesian Studies. Proceedings of the first conference on Indonesia's modern economic history, Jakarta, October 1-4, pp.123-148 (1991)

[10] H.W. Dick, "State, nation-state and National economy, pp. 17-18 (2002)

[11] The ports recorded are those whose export or import volume is at least $1 \%$ of Indonesia's total exports and imports.

[12] H.W. Dick, “Nineteeth-century industrialization: A missed, pp. 123 (1993) 